\title{
SIKAP DENGAN PERILAKU IBU RUMAH TANGGA TENTANG PENGGUNAAN MINYAK JELANTAH \\ (Di Desa Kumendung Kecamatan Muncar Kabupaten Banyuwangi)
}

\author{
Heru Prastiyawan ${ }^{1}$ Inayatur Rosyidah ${ }^{2}$ Wahyono $^{3}$ \\ ${ }^{12}$ STIKes Insan Cendekia Medika Jombang ${ }^{3}$ STIKes Borneo Cendekia Medika \\ Pangkalan Bun \\ ${ }^{1}$ email : heruprastiyawan@gmail.com, ${ }^{2}$ email : inrosyi@gmail.com, ${ }^{3}$ email : \\ wahyono@gmail.com
}

\begin{abstract}
ABSTRAK
Pendahuluan, Penggunaan minyak jelantah untuk memasak masih digunakan oleh ibu-ibu rumah tangga. Ibu rumah tangga menggunakan minyak goreng digunakan secara berulang-ulang, sampai bahan makanan habis. Tujuan penelitian adalah menganalisis sikap dengan perilaku ibu rumah tangga tentang pengunaan minyak jelantah di Desa Kumendung. Desain, penelitian analytic correlation, pendekatan cross sectional, tempat penelitian di Rt. 02 Rw. 04 Desa Kumendung, populasi seluruh ibu rumah tangga di Rt. 02 Rw. 04 Desa Kumendung sejumlah 80 ibu rumah tangga. Sampelnya 67 responden dengan menggunakan Simple random sampling. Variabel independen adalah sikap ibu rumah tangga dan variabel dependen adalah perilaku ibu rumah tangga. Alat ukur yaitu kuesioner, pengolahan data mulai editing, coding, scoring dan tabulating. Analisis menggunakan uji chi square. Hasil, penelitian menunjukan 67 responden setengahnya yaitu 34 responden $(50,7 \%)$ memiliki sikap negatif dan hampir setengahnya yaitu 33 responden $(49,3 \%)$ memiliki sikap positif tentang penggunaan minyak jelantah. Sedangkan perilaku ibu rumah tangga tentang penggunaan minyak jelantah dari 67 responden sebagian besar berperilaku negatif 38 responden $(56,7 \%)$, hampir setengahnya yaitu 29 responden $(43,3 \%)$ berperilaku positif tentang penggunaan minyak jelantah. Hasil uji chi square 0,000 menunjukan nilai $\mathrm{p}<0,05$ maka $\mathrm{H} 1$ diterima. Kesimpulan, ada hubungan antara sikap dengan perilaku ibu rumah tangga tentang penggunaan minyak jelantah di Rt. 02 Rw. 04 Desa Kumendung Kecamatan Muncar Kabupaten Banyuwangi.
\end{abstract}

Kata kunci: Minyak jelantah, Perilaku, Sikap.

\section{ATTITUDE WITH HOUSEHOLD MOTHER BEHAVIOR ABOUT USE OF OIL JELANTAH}

(In Kumendung Village, Muncar Sub-district, Banyuwangi District)

\begin{abstract}
Introduction, The use of cooking jelantah oil for cooking is still used by housewives. Housewives use cooking jelantah oil used repeatedly, until the food is used up. The purpose of this research is to analyze the attitude with the housewife's behavior about using jelantah oil in Kumendung Village. Analytic correlation research design, cross sectional approach, research site at Rt. 02 Rw. 04 Kumendung Village, the population of all housewives in Rt. 02 Rw. 04 Village Kumendung a number of 80
\end{abstract}


housewives. Samples were 67 respondents using Simple random sampling. The independent variable is the attitude of the housewife and the dependent variable is the behavior of the housewife. Measurement tool is questionnaire, data processing start editing, coding, scoring and tabulating. The result, analysis used chi square test The result showed 67 respondents half of them were 34 respondents $(50,7 \%)$ had negative attitude and almost half that 33 respondents (49,3\%) had positive attitude about the use of cooking oil. While the behavior of housewife about the use of cooking oil from 67 respondents mostly negative behavior 38 respondents (56,7\%), almost half that is 29 respondents $(43,3 \%)$ positive behavior about the use of cooking jelantah oil. The result of chi square test 0.000 shows $p$ value $<0,05$ then $\mathrm{Hl}$ is accepted. Conclusion, There is a relationship between attitude and behavior of housewife about the use of cooking jelantah oil in Rt. 02 Rw. 04 Village Kumendung District Muncar Banyuwangi District.

Keywords: Jelantah oil, Behavior, Attitude.

\section{PENDAHULUAN}

Krisis ekonomi melanda belahan dunia, tidak terkecuali negara Indonesia, telah membuat ibu rumah tangga berupaya secermat mungkin mengelola pengeluaran kebutuhan keluarga, dengan penggunaan minyak goreng berulang. Penggunaan minyak goreng dalam ruang lingkup ibu rumah tangga, pedagang dan pelaku usaha rumah makan, akan dimanfaatkan berulang kali dalam penggorengan makanan (Kandarwati dan Wahyuni, 2010, 6). Minyak goreng yang digunakan berulang kali (> 2 kali) tanpa penambahan minyak goreng baru biasanya disebut minyak jelantah (Fransiska, 2010, 4).

Penggunaan minyak jelantah untuk memasak masih digunakan oleh ibu-ibu rumah tangga. Ibu rumah tangga menggunakan minyak goreng dengan cara berulang-ulang, sampai bahan makanan yang digoreng habis, sehingga akan menghasilkan minyak goreng bekas (jelantah), minyak jelantah tersebut akan digunakan kembali untuk proses penggorengan selanjutnya. Ibu rumah tangga beranggapan, bahwa menggoreng menggunakan minyak jelantah, rasa yang dihasilkan akan lebih gurih, dan menambah citra rasa makanan, (Azizah, 2014, 4).

Hasil pendataan Badan Pusat Statistik (BPS) Kabupaten Jawa Timur (2016, 4), mencatat jumlah penduduk miskin di Jawa Timur yaitu $12,28 \%$, dari jumlah penduduk 38,847.561 jiwa Badan Pusat Statistik (BPS) dan Dinas Kependudukan dan Pencatatan Sipil Kabupaten Banyuwangi (2015, 5), mencatat jumlah penduduk miskin yaitu 147.700 jiwa $(9,29 \%)$, dari jumlah penduduk 1,668,438 juta jiwa.

Hasil penelitian yang dilakukan Warouw (2015, 5), tentang pengetahuan sikap dengan tindakan penggunaan minyak jelantah pada pelaku usaha rumah makan, di Kelurahan Bahu Kecamatan Malayang Kota Manado 2015, didapatkan hasil, sebagian pelaku usaha rumah makan, memiliki sikap dan perilaku yang tidak baik, tentang penggunaan minyak jelantah. Hal tersebut menunjukan bahwa, jumlah penggunaan minyak 
jelantah masih banyak dilakukan, dikalangan pelaku usaha rumah makan.

Hasil studi pendahuluan yang dilakukan di Rt. 02 Rw. 05 Dusun Palodem, Desa Sumbersewu, Kecamatan Muncar, Kabupaten Banyuwangi, yang dilakukan oleh peneliti, tentang sikap dan perilaku penggunaan minyak jelantah, menyatakan seluruh responden masih menggunakan minyak goreng berulang kali (jelantah).

Sikap penggunaan minyak jelantah masih saja sering dilakukan para ibu rumah tangga, penggunaan tersebut membuat ibu rumah tangga dapat mengurangi biaya pengeluaran keluarga, sehingga peggunaan minyak goreng berulang kali pun akan dilakukan, padahal minyak goreng bekas (jelantah), bisa berpotensi menimbulkan penyakit degeneratif. Penggunaan minyak goreng (jelantah), akan menghasilkan Asam Lemak Trans yang akan mempengaruhi produksi profil lipid dalam darah, yakni kolesterol, jika kandungan kolesterol dalam darah mengalami peningkatan, maka hal tersebut akan menimbulkan gejala Atherosklerosis, (Azizah, 2014, $6)$.

Upaya untuk mengurangi sikap dan perilaku ibu rumah tangga tentang penggunaan minyak jelantah, untuk keperluan menggoreng makanan, maka perlu dilakukan upaya-upaya untuk meningkatkan mutu dari minyak goreng bekas tersebut, sehingga ibu rumah tangga yang menggunakan minyak goreng bekas (jelantah), akan mendapatkan peningkatan mutu dari kandungan minyak goreng bekas tersebut. Peningkatan mutu minyak goreng bekas (jelantah), bisa dilakukan dengan menggunakan buah mengkudu yang sudah berupa serbuk (Juliana, Dkk., 2015, 183).

\section{METODE PENELITIAN}

Penelitian ini dilakukan di Rt. 02 Rw. 04 Desa Kumendung, Kecamatan Muncar, Kabupaten Banyuwangi. Penelitian ini dilakukan pada bulan Februari sampai Mei 2018. Penelitian ini merupakan penelitian non eksperimental, jenis penelitian ini adalah penelitian kuantitatif. Penelitian ini menggunakan desain penelitian analytic correlation dengan pendekatan cross sectional.

Populasi pada penelitian ini adalah seluruh ibu rumah tangga di Rt. $02 \mathrm{Rw}$. 04 Desa Kumendung, sebanyak 80 ibu rumah tangga dengan sample sejumlah 67 ibu rumah tangga.

Teknik sampling yang digunakan pada penelitian ini adalah simple random sampling. Simple random sampling digunakan dalam penelitian ini karena pengambilan sampel dilakukan secara acak, tanpa memperhatikan strata yang ada dalam populasi dan bersifat homogen (Sujarweni, 2014,178).

Instrumen yang digunakan pada penelitian ini adalah kuesioner dari dua variable. Kuesioner yang digunakan sudah di uji validitas dan uji reliabilitas sebelumnya. Isi dari kuesioner ini meliputi identitas responden dan pertanyaan-pertanyaan mengenai sikap dan perilaku penggunaan minyak jelantah. Analisa data meliputi analisa univariat dan bivariat menggunakan uji chi square dengan $\alpha=0,05$. 


\section{HASIL PENELITIAN}

\section{Data Umum}

Tabel 1. Distribusi frekuensi berdasarkan umur ibu rumah tangga Rt. 02 Rw. 04 Desa Kumendung Tahun 2018 .

\begin{tabular}{ccc}
\hline Umur (Tahun) & Jumlah & Persentase $(\%)$ \\
\hline $22-26$ & 4 & 6,0 \\
$27-31$ & 23 & 34,3 \\
$32-36$ & 21 & 31,3 \\
$37-41$ & 15 & 22,4 \\
$>42$ & 4 & 6,0 \\
\hline Total & 67 & 100 \\
\hline
\end{tabular}

Sumber: Data primer Mei 2018

Berdasarakan tabel 1. menunjukan hampir setengahnya usia ibu rumah tangga Rt. 02 Rw. 04 Desa Kumendung adalah 27-31 Tahun sebanyak 23 ibu rumah tangga $(34,3 \%)$.

Tabel 2 Distribusi frekuensi berdasarkan pendidikan ibu rumah tangga Rt. 02 Rw. 04 Desa Kumendung Tahun 2018.

\begin{tabular}{ccc}
\hline Pendidikan & Jumlah & Persentase $(\%)$ \\
\hline Tidak Sekolah & 7 & 10,4 \\
SD & 27 & 40,3 \\
SMP & 22 & 32,8 \\
SMA & 8 & 11,9 \\
PT & 3 & 4,5 \\
\hline Total & 67 & 100
\end{tabular}

Sumber: Data primer Mei 2018

Berdasarakan tabel 2 menunjukan hampir setengahnya pendidikan ibu rumah tangga Rt. 02 Rw. 04 Desa Kumendung adalah SD sebanyak 27 ibu rumah tangga $(40,3 \%)$.

Tabel 3 Distribusi frekuensi berdasarkan pekerjaan ibu rumah tangga Rt. 02 Rw. 04 Desa Kumendung Tahun 2018.

\begin{tabular}{ccc}
\hline Pekerjaan & Jumlah & Persentase $(\%)$ \\
\hline Petani & 32 & 47.8 \\
Buruh & 21 & 31.3 \\
Wiraswasta & 9 & 13.4 \\
Swasta & 3 & 4.5 \\
PNS & 2 & 3.0 \\
\hline Total & 67 & 100 \\
\hline Sumb
\end{tabular}

Sumber: Data primer Mei 2018

Berdasarakan tabel 3 menunjukan hampir setengahnya pekerjaan ibu rumah tangga Rt. 02 Rw. 04 Desa Kumendung adalah petani sebanyak 32 ibu rumah tangga $(47,8 \%)$.

Tabel 4 Distribusi frekuensi berdasarkan mendapatkan informasi ibu rumah tangga Rt. 02 Rw. 04 Desa Kumendung Tahun 2018.

\begin{tabular}{c|c|c}
\hline $\begin{array}{c}\text { Mendapatkan } \\
\text { informasi }\end{array}$ & Jumlah & Persentase (\%) \\
\hline Ya & 67 & 100 \\
Tidak & 0 & 0 \\
\hline Total & 67 & 100 \\
\hline
\end{tabular}

Sumber: Data primer Mei 2018

Berdasarakan tabel 4 menunjukan seluruh ibu rumah tangga Rt. 02 Rw. 04 Desa Kumendung mendapatkan informasi dengan kategori Ya sebanyak 67 ibu rumah tangga (100\%).

Tabel 5 Distribusi frekuensi berdasarkan sumber informasi ibu rumah tangga Rt. 02 Rw. 04 Desa Kumendung Tahun 2018.

\begin{tabular}{ccc}
\hline Sumber informasi & Jumlah & Persentase (\%) \\
\hline Tetangga & 4 & 6.0 \\
Buku & 6 & 9.0 \\
Radio & 3 & 4.5 \\
Televisi & 49 & 73.1 \\
Tenaga Kesehatan & 2 & 3.0 \\
Internet & 3 & 4.5 \\
\hline Total & 67 & 100 \\
\hline
\end{tabular}

Sumber: Data primer Mei 2018

Berdasarakan tabel 5 menunjukan sebagian besar tempat mendapatkan sumber informasi ibu rumah tangga Rt. 02 Rw. 04 Desa Kumendung adalah 
televisi sebanyak 49 ibu rumah tangga $(73,1 \%)$.

\section{Data Khusus}

Tabel 6 Sikap ibu rumah tangga tentang penggunaan minyak jelantah Tahun 2018.

\begin{tabular}{ccc}
\hline Sikap & Jumlah & Persentase (\%) \\
\hline Positif & 33 & 49,3 \\
Negatif & 34 & 50,7 \\
\hline Total & 67 & 100 \\
\hline
\end{tabular}

Sumber: Data primer Mei 2018

Pada tabel 6 Menunjukan setengahnya sikap ibu rumah tangga tentang penggunaan minyak jelantah adalah negatif sebanyak 34 ibu rumah tangga $(50,7 \%)$

Tabel 7 Perilaku ibu rumah tangga tentang penggunaan minyak jelantah Tahun 2018.

\begin{tabular}{ccc}
\hline Perilaku & Jumlah & Persentase (\%) \\
\hline Positif & 29 & 43.3 \\
Negatif & 38 & 56.7 \\
\hline Total & 67 & 100.0 \\
\hline
\end{tabular}

Sumber: Data primer Mei 2018

Pada tabel 7 Menunjukan sebagian besar perilaku ibu rumah tangga tentang penggunaan minyak jelantah adalah negatif sebanyak $38 \mathrm{ibu}$ rumah tangga $(56,7 \%)$.

Tabel 8 Hubungan sikap dengan perilaku ibu rumah tangga tentang penggunaan minyak jelantah Tahun 2018.

\begin{tabular}{ccccccc}
\hline \multirow{2}{*}{ Sikap } & \multicolumn{3}{c}{ Perilaku } & \multicolumn{2}{c}{ Total } \\
\cline { 2 - 5 } & \multicolumn{2}{c}{ Positif } & \multicolumn{2}{c}{ Negatif } & \multirow{2}{*}{ n } & $\%$ \\
\cline { 2 - 5 } Positif & 12 & 17,9 & 21 & 31,3 & 33 & 49, \\
Negatif & 17 & 25,4 & 17 & 25,4 & 34 & 50,7 \\
\hline Total & 29 & 43,3 & 38 & 56,7 & 67 & 10 \\
& \multicolumn{4}{c}{ Uji Chi Square: $p=0,000$} \\
\hline Sumber: Data primer Mei 2018
\end{tabular}

Pada tabel 8 tersaji bahwa dari 67 responden hampir setengahnya mempunyai sikap dan perilaku negatif terhadap penggunaan minyak jelantah sebanyak 38 ibu rumah tangga $(56,7 \%)$.

Hasil analisis dengan menggunakan bantuan program komputer SPSS 16, didapatkan hasil analisis chi square 0,000 yang menunjukan bahwa nilai $\mathrm{p}<0,05$. Maka $\mathrm{H} 1$ diterima dan $\mathrm{H} 0$ ditolak atau ada hubungan antara sikap dengan perilaku ibu rumah tangga tentang penggunaan minyak jelantah di Rt. 02 Rw. 04 Desa Kumendung, Kecamatan Muncar, Kabupaten Banyuwangi.

\section{PEMBAHASAN}

Sikap Ibu Rumah Tangga Tentang Penggunaan Minyak Jelantah

Hasil penelitian dengan analisa univariat terhadap data responden terhadap sikap penggunaan minyak jelantah didapatkan hasil, setengah responden memiliki sikap negatif tentang penggunaan minyak jelantah, sebanyak 34 ibu rumah tangga $(50,7 \%)$.

Hal ini didasarkan pada nilai indikator rata-rata terendah pada kuesioner sikap ibu rumah tangga pada parameter afektif $(2,8)$, dan konotatif $(2,97)$ dengan kategori tidak setuju terhadap pernyataan yang diberikan. Hasil data yang sudah terkumpul dari jawaban responden, dapat dikatagorikan berdasarkan jawaban responden, adalah tidak setuju terhadap pernyataan yang diberikan berdasarkan parameter afektif. Hal tersebut menunjukan setengahnya ibu rumah tangga tidak memikirkan atau tidak mengetahui dan 
mempermasalahkan kandungan gizi dari minyak jelantah yang digunakan. Berdasakan kategori dari jawaban responden menunjukan aspek afektif yang dimiliki ibu rumah tangga tentang penggunaan minyak jelantah tersebut rendah, maka akan menimbulkan sikap negatif terhadap penggunaan minyak jelantah. Aspek konotatif sendiri merupakan aspek yang ditimbulkan dari pengetahuan, penilaian terhadap sesuatu objek. Jika aspek konotatif yang dimiliki ibu rumah tangga kurang, hal tersebut akan membuat sikap ibu rumah tangga tentang penggunaan minyak jelantah menjadi negatif.

Sikap adalah respon tertutup seseorang terhadap stimulus atau objek tertentu, yang sudah melibatkan faktor pendapat dan emosi yang bersangkutan (senang tidak senang, setuju tidak setuju, baik tidak baik, dan sebagainya) Sikap juga terdiri dari komponen-komponen sikap sendiri yaitu kognitif, afektif dan konotatif (Notoatmodjo, 2014, 88). Sikap tentang penggunaan minyak jelantah oleh ibu rumah tangga sering dilakukan karena, dapat mengurangi biaya pengeluaran keluarga (Azizah, 2014, 4).

\section{Perilaku Ibu Rumah Tangga Tentang Penggunaan Minyak Jelantah.}

Hasil penelitian dengan analisa univariat terhadap data responden terhadap perilaku penggunaan minyak jelantah didapatkan hasil, sebagian besar perilaku ibu rumah tangga tentang penggunaan minyak jelantah adalah negatif sebanyak 38 ibu rumah tangga $(56,7 \%)$. Hal ini didasarkan pada nilai indikator rata-rata terendah pada kuesioner perilaku ibu rumah tangga, yaitu pada parameter frekuensi penggunaan minyak jelantah $(2,8)$, cara penggunaan minyak jelantah $(3,00)$ dan kebersihan tempat menggoreng $(3,16)$ dengan kategori sering melakukan terhadap pernyataan yang diberikan.

Pernyataan dengan parameter frekuensi penggunaan minyak jelantah membahas tentang pemilihan penggunaan minyak goreng baru dengan minyak jelantah untuk setiap kali mengolah makanan. Berdasarkan hasil jawaban dari kuesioner tersebut, dapat dikategorikan responden sering melakukan pengolahan makanan menggunakan minyak jelantah. Hal tersebut menunjukan ibu rumah tangga tidak peduli dengan pemilihan minyak goreng baru atau minyak jelantah untuk setiap mengolah makanan, karena ibu rumah tangga lebih memikirkan bagaimana cara meminimalkan pengeluaran keluarganya. Hal tersebut menyebabkan ibu rumah tangga memiliki perilaku negatif terhadap penggunaan minyak jelantah.

$\begin{array}{lcr}\text { Pernyataan } & \text { kuesioner } & \text { yang } \\ \text { berdasarkan } & \text { parameter } & \text { cara } \\ \text { penggunaan } & \text { minyak } & \text { jelantah, }\end{array}$ membahas tentang cara penggunaan minyak jelantah. Berdasarkan hasil jawaban responden dapat dikategorikan ibu rumah tangga sering melakukan cara penggunaan minyak goreng yang salah setiap mengolah makanan. Hal tersebut menunjukan cara menggunaan minyak goreng baru maupun minyak jelantah dengan cara yang salah setiap mengolah makanan. Sehingga hal tersebut dapat menimbulkan perilaku negatif terhadap cara penggunaan minyak jelantah.

Kuesioner dengan parameter kebersihan tempat menggoreng makanan. Kuesioner tersebut membahas tentang membersihakan tempat penggorengan sebelum mengganti minyak goreng bekas atau 
minyak jelantah dengan minyak goreng baru. Berdasarkan jawaban responden dari kuesioner tersebut dapat dikategorikan responden sering melakukan pembersihan tempat penggorengan sebelum mengganti minyak goreng bekas atau minyak jelantah dengan minyak goreng baru, dengan cara yang salah.

Hal tersebut dikarenakan ibu rumah tangga sering melakukan pembersihan tempat penggorengan sebelum mengganti minyak goreng bekas dengan minyak goreng baru, hanya dengan membuang minyak goreng bekas tanpa mencuci tempat penggoreng tersebut. Sehingga membuat minyak goreng bekas masih tersisa ditempat penggorengan. Hal tersebut akan menyebabkan perilaku negatif ibu rumah tangga tentang penggunaan minyak jelantah.

Perilaku adalah semua kegiatan atau aktivitas manusia baik yang dapat diamati langsung, maupun yang tidak dapat diamati oleh pihak luar. Perilaku dapat berubah secara relatif dan dapat dipengaruhi oleh hal-hal lain diantaranya intelegensi, emosi dan lingkungan (Notoatmodjo, 2014, 88). Penggunaan minyak jelantah dapat menyebabkan timbulnya penyakit pembuluh darah, akan tetapi ibu rumah tangga beranggapan, bahwa penggunaan minyak jelantah untuk memasak akan menambah citra rasa makanan dan dapat mengurangi biaya pengeluaran keluarga, perilaku negatif terhadap penggunaan minyak jelantah pun tetap dilakukan (Azizah, 2014, 4).

Salah satu faktor yang dapat mempengaruhi dalam penggunaan minyak jelantah yaitu pekerjaan. Tidak semua orang yang mempunyai pekerjaan mendapatkan penghasilan yang lebih.

Pekerjaan adalah keburukan yang harus dilakukan, terutama untuk menunjang kehidupannya dan kehidupan keluarganya. Pekerjaan bukanlah sumber kesenangan, tetapi merupakan cara mencari nafkah yang membosankan, berulang dan banyak tantangan dan tidak selalu pekerjaan yang dilakukan menghasilkan hasil yang banyak (Mubarak, 2010, 5).

\section{Hubungan Sikap Dengan Perilaku Ibu Rumah Tangga Tentang Penggunaan Minyak Jelantah.}

Berdasarkan uji bivariat didapatkan hasil, hampir setengahnya dari 67 responden mempunyai sikap dan perilaku negatif terhadap penggunaan minyak jelantah sebanyak 38 ibu rumah tangga (56,7\%). Hasil anlisis dengan menggunakan bantuan program komputer SPSS 16, didapatkan hasil analisis chi square 0,000 menunjukan bahwa nilai $\mathrm{p}<0,05$ maka $\mathrm{H} 1$ diterima dan H0 ditolak, atau ada hubungan antara sikap dengan perilaku ibu rumah tangga tentang penggunaan minyak jelantah di Rt. 02 Rw. 04 Desa Kumendung, Kecamatan Muncar, Kabupaten Banyuwangi.

Individu yang sudah mempunyai pengetahuan dan sikap terhadap sesuatu objek, maka dengan faktor emosi seperti suka atau tidak suka terhadap suatu objek, maka seseorang akan melakukan kecenderungan bertindak. Kecenderungan bertindak tersebut merupakan perilaku individu yang berdasarkan pengetahuan dan sikap yang diperoleh dari suatu stimulus atau suatu objek. Perilaku positif atau negatif sangat ditentukan dari pengetahuan dan sikap seseorang 
terhadap sesuatu objek (Notoatmodjo, 2014, 99).

\section{KESIMPULAN DAN SARAN}

\section{Kesimpulan}

Hasil penelitian yang sudah dilakukan dapat disimpulkan sebagai berikut:

1. Sikap ibu rumah tangga tentang penggunaan minyak jelantah di Rt. 02 Rw. 04 Desa Kumendung, Kecamatan Muncar, Kabupaten Banyuwangi setengahnya negatif sebanyak 34 responden $(50,7 \%)$.

2. Perilaku ibu rumah tangga tentang penggunaan minyak jelantah di Rt. 02 Rw. 04 Desa Kumendung, Kecamatan Muncar, Kabupaten Banyuwangi sebagian besar negatif sebanyak 38 responden $(56,7 \%)$.

3. Ada hubungan antara sikap dengan perilaku ibu rumah tangga tentang penggunaan minyak jelantah di Rt. 02 Rw. 04 Desa Kumendung, Kecamatan Muncar, Kabupaten Banyuwangi.

\section{Saran}

1. Kepada ibu rumah tangga

Diharapkan ibu rumah tangga tidak lagi menggunakan minyak jelantah untuk mengolah makanan, dan memahami efek dari penggunaan minyak jelantah bagi kesehatan.

2. Kepada perawat komunitas puskesmas

Diharapkan kepada perawat komunitas puskesmas setempat, agar memberikan sosialisasi atau seminar tentang bahaya penggunaan minyak jelantah, khususnya kepada ibu rumah tangga agar tidak lagi menggunakan minyak jelantah untuk mengolah makanan.

3. Kepada kader kesehatan
Diharapakan kepada kader kesehatan untuk mengingatkan kepada ibu rumah tangga agar tidak lagi menggunakan minyak jelantah untuk mengolah makanan.

4. Kepada peneliti selanjutnya

Diharapkan bagi peneliti selanjutnya dapat melakukan penelitian cara meningkatkan mutu minyak jelantah.

\section{DAFTAR PUSTAKA}

Azizah. 2014. Pengetahuan Ibu Rumah Tangga Tentang Bahaya Minyak Goreng Bekas (Jelantah) Bagi Kesehatan. UMPO: Ponorogo.

Badan Pusat Statistik (BPS) dan Dinas Kependudukan dan Penctatan Sipil Kabupaten Banyuwangi. 2015. Awal 2015 BPS Update Data PPLS. Diakses dalam http://www.banyuwangikab.go.id /berita-daerah/awal-2015-bpsupdate-data-ppls.html. Pukul 13.00 WIB.

Badan Pusat Statistik (BPS) Jawa Timur. 2016. Profil Kemiskinan di Jawa Timur. diakses dalam https://jatim.bps.go.id/Brs/view/i d/434. Pukul 12.30 WIB.

Fransiska, E. 2010. "Karakteristik, pengetahuan, sikap dan tindakan ibu rumah tangga tentang penggunaan minyak goreng berulang kali". Universitas Sumatera Utara: Medan.

Juliana, Dkk. 2015. "Pemanfaatan buah mengkudu (Morinda Citrifolia l.) sebagai adsorben untuk meningkatkan mutu minyak jelantah". Universitas Tadokulo Palu: vol. 4 no. 4. 
Kadarwati dan Wahyuni. 2010.

"Regenerasi minyak jelantah dengan zeolit alam sebagai upaya peningkatan kesehatan masyarakat". Prodi Kimia FMIPA Universitas Negeri Semarang. vol. 08.

Mubarak. 2010. Ilmu keperawatan komunitas konsep dan aplikasi. Selemba Medika: Jakarta

Notoatmodjo, S. 2014. Ilmu perilaku kesehatan. Rineka Cipta: Jakarta.

Sujarweni, V, W. 2014. Metodologi Penelitian Keperawatan. Gava Media: Yogyakarta.

Warouw, Janis A, Mikhael. 2015. "Hubungan antara pengetahuan dan sikap dengan tindakan penggunaan minyak jelantah pada pelaku usaha rumah makan". Universitas Sam Ratulangi Manado. Vol.3, 